Јелица Стојановић*

Универзитет Црне Горе

Филолошки факултет

Студијски програм за српски језик и књижевност

https://doi.org/10.18485/ai_zsjoski.2019.2.ch6

821.163.41.09-31 Вуксановић М.

811.163.41'36

\title{
СЕМОЉ ЉУДИ У ОГЛЕДАЛУ СЛОЖЕНИЦА У СЕМОљ ЉУДИМА МИРА ВУКСАНОВИТА
}

Циљ нашег рада је да представимо ријечи са двије основе у Семољ љуяима Мира Вуксановића. Роман Семољь љьgи показује да овај лексички слој није риједак у српском језику. Помоћу овог типа покушали смо да представимо какви су семољ људи у Азбучном роману у 919 прича о надимцима.

Кључне ријечи: ријечи са двије основе, сложенице, сложено-изведене ријечи, творбена основа, лексички састав, суфикс, интерфикс, позитивна конотација, негативна конотација, ласцивне ријечи.

1. Дјело Мира Вуксановића представља право и ријетко језичко благо, којим је показана, али и обогаћена ризница српске ријечи. Његови речници-романи чувају ријечи од нестајања и заборава, дајући, истовремено, ријечима дубоки смисао причом ријечима, и о ријечима. Како налазимо код Мира Вуксановића: „Реч је мало биће које се с другим малим бићима истог рода и истог соја окупља у језик”. Ријеч је лична и заједничка. На једној страни: „Реч је родни лист сваког писца. Она

* jelicast@yahoo.com 
му одређује дан, месец и годину рођења, Божији знак и друге поруке са неба. Писац расте у речима" (Језик - кућа од речи). Истовремено: „... реч одјекује по дубини наше културе, културе и књижевности као огромног и спасоносног памћења". Свака ријеч у дјелу Мира Вуксановића је и ријеч, и прича ријечи, и прича о ријечи, о животу, земљи, човјеку. Идући за оним, како би рекао Миро Вуксановић, да постоје „ријечи-кључеви”, те покушавајући да пронађемо ријечи-кључеве које ће најбоље одсликати и откључати срж ријечи у дјелу М. Вуксановића, опредјелили смо се за ријечи састављене од двије основе (сложенице, изведене сложене ријечи, сраслице) у Семоль љуgима. Зашто за ријечи састављене од двије основе? Зато што те ријечи носе наслојена значења (саставних дјелова, гдје свака ријеч уноси своје значење, али стопљене заједно ријечи добијају и ново значење), ријечи састављене од двије основе су реченице у малом, цијеле мисли, наслојено мисаоно и животно искуство. Нарочито када су слика и прилика човјека, Семољ човјека.

За словенске језике у литератури се, као опште мјесто, може срести мишљење да нијесу нарочито склони творби слагањем, те да словенски језици из прасловенског насљеђују релативно ограничен број ријечи састављених од двије основе. Савремена испитивања донекле, рекло би се, мијењају, или преиспитују, овакво традиционално мишљење јер, према новијим истраживања (и историјских и савремених словенских дијалеката), сложенице нијесу стране словенским говорима. ${ }^{1}$ Недостају потпуније студије у вези са овом проблематиком, а ни дијалекатска лексика (али ни лексика писаног језика) овог типа такође већином није сакупљена, испитана и обрађена.

1 Постоје и у староруским повељама XI-XIV вијека, и у савременим српским и бугарским дијалектима (Ћупић Д. - Ћупић Ж.: 1997; Кочев и др. 1988; Вялкина 1966: 156-195), гдје су могле бити наслијеђене и из давнина (Грковић-Мејџор 2007: 397-398). 
Да српски језик није сиромашан ријечима састављеним од двије основе, него напротив, показује и књига Семоль љуgи, као и, између осталог, Рјечник Вука Стефановића Караџића (код кога су ријечи овог типа сасвим обичне, и честе) (Стојановић 2018: 209-219). Ексцерпирали смо преко 80 ријечи са двије основе различитог типа у Семољ љьуgима. Осим што представља ризницу српског језика, овај језички слој нам говори и о самом књижевном дјелу, о Семољ људима, њиховим карактерима, изгледу, особинама, животу. У овом раду мање ћемо се бавити граматичком страном ријечи са двије основе, а, још више семантиком, јер је тај аспект важнији за увид у само књижевно дјело и Семољ људе.

2. Сложенице смо класификовали у оквиру одговарајућих творбених категорија, и унутар тих категорија груписали смо их према начинима творбе и творбеним моделима. Посебну пажњу посветили смо лексичком саставу сложеница.

Све сложеница су именичке, што је и логично јер квалификују човјека (његов физички изглед или његов карактер, а најчешће и једно и друго, у сплету и [не] сагласју), а углавном су настале композицијом и комбинацијом композиције и суфиксације.

Најфреквентнији тип је придјевска основа + именичка основа (око 18 примјера), што је условљено тиме што се износи квалификација: физичка или психичка (карактерна) особина, нпр: gивносава (126), вайрока (64), жарока (168), злоиуийник (191), злоумница (193), крайконоіиле (250), мекообразнииа (295), мучноїуз (304), ошитрокониа (366), руюокур (422), руюіууз(иле), руюgуй(иле), руюо-

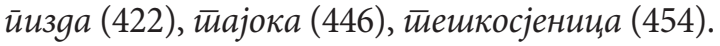

Незнатно мање фреквенције представља тип глаголска основа + именица (око 15 примјера). Највећи број је са императивом у првом дијелу: Бечока (44), вртичиіуза, 75, 
вуцирейа (78), вуиммкк (79), велибаша (121), жалийркна (166), жиликур (174), јамиіуз (214), набиіуз (306), невиябрав (326), немрчийушка (328), остиојбаша (363), йазиі̄уза (367), иаликућа (370), вежеіррабица (66).

Тип именичка основа + глаголска основа је најфреквентнији у српском језику, али не и у Семољ љьgима, што је, опет, условљено семантиком ријечи, тј. тематским оквиром (12): боїобитиина (51), іовноћера (97), іолоіурриле (98), іоройаgник (101), ірромобитинииа (107), gаніуубица (116), злослуй (192), злотичи (192), куроитресина (256), крвомуйнища (251), љууоройка (275), ииушконоша (403).

Именичка основа + именичка основа (10): банgоілава (32), бороілавиле (51), вакмајстиор (61), Ђавомуg (150), женобама (171), живинgоба (173), иеленіаћа (376), змијока (192), клинууйа (242), сирранока (438).

Остали типови су забиљежени у мањем броју примјера: придјевска основа / прилог ${ }^{2}+$ глаголска основа (3): іолоіурриле (98), злослуй (192), злоииуи (192); замјеничка основа + именичка основа: еволик (159); бројна основа + именичка основа: gвоочка (117), gвоумаи (118); ономатопејске ријечи: блебейан (49), мућмуриле (303).

Није велики број примјера који је настао срастањем: бишћела (48), вакмајстиор (61), оберлуйеж (346), вежеірабица (66), ииамоони (449).

Дакле, најфреквентнији тип је придјевска основа + именичка основа, потом именичка основа + глаголска основа; слиједе: глаголска основа + именица; именичка основа + именичка основа, придјевска основа / прилог + глаголска основа, бројна основа + именичка основа, именичка основа + именичка основа, итд. Сложенице у Семољ људима су настале комбинацијом различитих саставних дјелова. Најфреквентнији тип је са придје-

2 Када је у првом дијелу прилог, у питању могу бити сраслице, гдје је -о саставни дио прилога. 
вом у првом дијелу којим се уноси највише семантичког потенцијала за квалификацију Семољ људи. Веома су фреквентни типови са глаголом (прије свега у првом, али и у другом дијелу) што нам говори да су се Семољ људи одређивали и с обзиром на оно чиме се баве (да им је то одређивало и карактерне и физичке предиспозиције).

3. Чести су турцизми, при чему оба саставна дијела могу бити из турског, или само један дио. Када су то ријечи састављене од двије основе у турском, у српском се често не доживљавају као сложенице, али оне које у једном дијелу садрже српску основу представљају сложенице: $\delta а м \delta р е к,{ }^{3} \delta u м \delta а ш а,{ }^{4}$ gелибаша, ${ }^{5}$ потом сложенице са „баша” из турског у другом дијелу, остиојбаша, женобаша (171); оштироконца. ${ }^{6}$ Турцизми имају посебан семантички набој, наслојени су значењем из турског, углавном су пресемантизовани, често добили и нову и јачу експресивност у српском.

4. Најчешћи начин грађења сложеница јесте помоћу интерфикса, што, како се наводи у литератури, представља традиционални индоевропски начин слагања. Александар Белић сложенице дијели на двије групе, од којих је једна новија по постанку (настала срастањем), а друга старија (са спојним вокалом), тј. разликује „синтагматске спојеве новијег доба, у којима свака сложеница представља део реченице, управо групу речи синтаксички (функцијом и значењем) повезане” и „сложенице синтагматске старијег доба или сложенице са спојним

3 Bambrek: bam- (tur.) sasvim, brek... (nadoći, nabubriti) (Škaljić 1966: 115).

4 Zapovjednik od hiljadu vojnika: bin, tur. hiljada, baša m (tur.) starješina, poglavar, prvak (Škaljić 1966: 144).

5 Делибаша: deli indecl. adj. (tur.) lud, mahnit, silovit, pomaman; baša, tur. junak; delibaša „prvak među delijama, najbolji junak, zapovjednik jednog odreda delija" (Škaljić 1966: 210).

6 Конџа: тур. koncolos „utvara, vampir” (Škaljić 1966: 415). 
вокалом о (или е)" (Белић 2000:109). Р. Маројевић говори о интерфиксу о и његовом аломорфу $е$, који могу бити замијењени нултим интерфиксом ø (Маројавић 2005: 695). Поставља се и питање да ли у „спојне вокале” „убројити -u- / -y- / -ø-, и када (Клајн 2002: 23-29; Барић 1980: 24, 26; Радић 2014: 27-49, Маројевић 2005: 691697, итд.), „или су формације типа боіуумил сраслице (са падежним $y$ ), а оне типа лезилебовић императивне сложенице" (Радић 2014: 29). Овдје се мишљења такође разликују, а појединачни примјери траже посебна тумачења (Маројевић 2005: 691-697). Остављајући по страни ове спорове, ми ћемо представити наш корпус у цјелини, уз употребу термина и модела који нам се чине најпогоднији за класификацију примјера.

Најчешће налазимо интерфикс -о-: банgоілава (32),

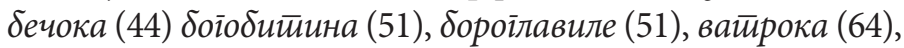
іовноћера (97), іолоїриле (98), іоройаgник (101), іромобитинииа (107), gвоочка (117), gвоумаи, (118), ђавомуд (150), жарока (168), женобаша (171), змијока (192), куроитресина (256), кратиконоіиле (250), крвомуйниияа (251), крчошија (252), тубороитка 8275), мекообразница (295), мучноіуз (304), ошитрокониа (366), иичсконоїа (381), йушконоша (403), руюокур (422), руюойизяа (422), ситранока (438), йајока

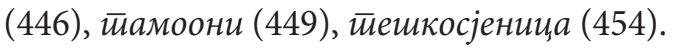

Није мали број ни примјера гдје се -о- јавља (или може посматрати) као саставни дио прилога у првом дијелу сраслице, нпр.: іолоіуриле (98), ђавомуg (150), еволик (159), злойуйник (191), злослуй (192), злойуи (192), злоумниияа (193), мучноіууз (304), стиокамеюак (438).

Части су примјери и са нултим интерфиксом: вуимук (79), gані̄убииа (116), клиняуйа (242), мажgритаи, (285), мућмуриле (303), иееленїаћа (376), руніууз(иле), руюяуй(иле), блебейан (49), алавук (14), аламуюа (15), даніубица (116).

У првом дијелу може бити и императивна форма, или 


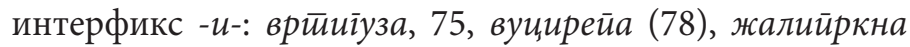
(166), жиликур (174), јамиіууз (214), набиіууз (306), невиябрав (326), остиојбаша (363), ӣазиіууза (367), йаликућа (370), йожмирей (388).

5. Највећи број сложеница добијен је комбиновањем композиције и суфиксације (22).

Најфреквентнији су примјери са суфиксима -a/-(u)ja:

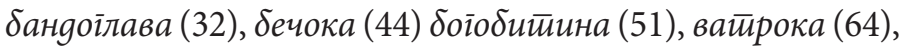

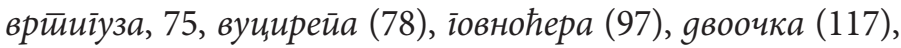
gивносава (126), жалииркна (166), жарока (168), змијока (192), клиндуйа (242), иееленіаћа (376), иуушконоша (403), стиранока (438), йајока (446), ћаластирача (460).

Чести су примјери са нултим суфиксом, иначе особина српског народног језика (за разлику од црквенословенског) (11). У Вуковом Рјечнику то је најфреквентнији тип: бамбрек (31), вуимук (79), ђавомуg (150), жиликур (174), злослуй (192), злойуи, (192), јамиіууз (214), јолитаз, мучноїуз (304), набиіууз (306), рунокур (422).

Са суфиксом -ица -u-/-аи, забиљежили смо 9 примјера: вежеірабиияа (66), ірромобитинииа (107), gаніуубииа (116), gвоумаи, (118), злоумниияа (193), крвомуитница (251), мажgрйаи, (285), мекообразница (295), иеешкосјении а (454).

Примјера у којима је у другом дијелу именица има такође знатан број (23): алавук (14), аламуна (15), бим-

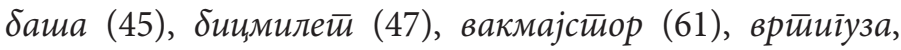
75, вуимук (79), делибаша (121), еволик (159), женобаша (171), живиндоба (173), злойуйник (191), крчошија (252), немрчийушка (328), оберлуйеж (346), остиојбаша (363), ошт̄рокониа (366), йазиіууа (367), йалазври (369), йаликућа (370), йожмиреи (388), иеешкосјеница (454).

Примјери са осталим суфиксом су појединачни (-je/ије, -ка, -ник/-нии, , к-/-че, -ина, -ан, -стиво -ости-ло/-ле, -ииа -ић; -она): блебетиан (49), бороілавиле (51), іологуриле (98), іоройаgник (101), злойуйник (191), куройре- 
сина (256), краииконойиле (250), стиокаменак (438), ћаласиирача (460), ћасламалка (461).

5. Какви су Семољ људи, с обзиром на оно што ријечи састављене од двије однове говоре о њима? Људи којима је живот одредио семољ. А семољ је: „велики снег, у наметима и капама, под урвовима, у китини. Семољ је и велика магла, густа, димљива, мокра, на планини, без издушка, ни прст пред носом. Семољ је облак, црн и тром, заваљен, ленчина, спуштен и недогледан... Семољ је и честа трава... Семољ је непрегледно камено точило... Семољ је огромна шума... у вучјем завијању. У Семољу су људи који су порасли из речи да населе гору и земљу" (431). А ту је и Семољка, која је ту рођена, огледала се у Семољу: „Она прича семољске приче” (431). Какви су људи семољски испричани од Семољке, у огледалу Семоља, сагледани кроз ријечи са двије основе? О томе нам, великим дијелом, говори и то што је више 4-5 пута ријечи које носе негативну квалификацији (63), од оних са позитивном или неутралном (15):

Забиљежено је 15 ријечи са двије основе које имају позитивно или неутрално значење: алавук (14), аламуюа (15), ватирока (64), вакмајстиор (61), gвоока (117), gелибаша (121), дивносава (126), жарока (168), женобама (171), гьуборойка (275), остиојбаша (363), иуушконоша (403), сирранока (438), ииајока (446).

Оних којим се означава негативна особина неупоредиво је више (63): бамбрек (31), баняоілава (32), бечока

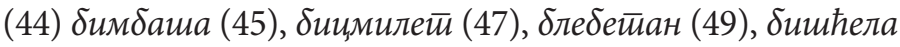

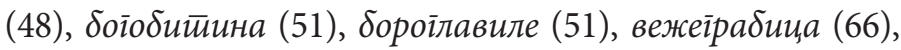
вртииіууза (75), вуцирейа (78), вуимук (79), іовноћера (97), іолоіуриле (98), іоройаgник (101), іромобитиница (107), gаніубииа (116), двоочка (117), gвоумаи, ђавомуд (150), еволик (159), жалийркна (166), женобаша (171), живинgоба (173), жаликур (174), злойуйник (191), злослуй (192), злотиуи (192), злоумница (193), змијока (192), јамиіууз (214), 
јолйаз, куроитресина (256), клинgуйа (242), краииконойиле (250), крвомутиница (251), крчомија (252), тьуороиика 8275), мажgрйаи (285), мекообразница (295), мућмуриле (303), мучноіуз (304), набиіуз (306), невиябрав (326), немрчийушка (328), оберлуйеж (346), оштірокониа (366), йазиіууза (367), йалазври (369), йаликућа (370), иееленіаћа (376), йисконоїа (381), йожмирей (388), руюокур (422), руюіууз(иле), руюяуй(иле), руюойизяа (422), сииокамеюак (438), стиранока (438), йајока (446), йамоони (449), иеешкосјенициа (454).

Судећи према нашем корпусу, Семољ људи су знатно чешће добијали квалификације са негативнним предзнаком, позитивне особине су се рјеђе и мање радо истицале, у складу са не баш наклоњеном земљом која у свом имену носи предзнак „семољ”, а то име је „надјенула” и земљи и љидима, у складу са приповједачем „Семољком”, која прича причу, која, опет, није била „блага на ријечима”.

6. Лексички састав сложенице је веома разнолик тако да је тешко издвојити нешто посебно карактеристично, осим појединачних детаља. У складу са Семољ земљом и људима, и причом Семољке, јављају се само ријечи са злоу првом дијелу, а ни једна са gобро-: злойуйник (191), злослуй (192), злойуи (192), злоумница (193). Иначе, и у Вуковом Рјечнику су чешће ријечи које у свом саставу имају зло- него gобро- (треба истражити како је то у српским рјечницима) (Стојановић 2017).

Доминирају, што носи посебну експресивност, ријечи састављене од двије основе које у првом или другом дијелу садрже ласцивну ријеч (чак 21 примјер), или имају ласцивно значење, без обзира на састав: вртииіуза, 75, іовноћера (97), жалийркна (166), жиликур (174), јамиїуз (214), куроитресина (256), клинgуйа (242), мучноїуз (304), набиїуз (306), йазиїуза (367), руюокур (422), руюіуузиле), руюgуй(иле), руюойизяа (422); бишћела (48), вуиирейа (78), тьуборотика (275), іолоіуриле, мекообраз- 
нииза (295), мућмуриле (303), стиокаменак (438), вуицрейа (78), йожмиреи (388).

Иначе, ласцивне ријечи су веома фреквентне и у Вуковом Рјечнику (Стојановић 2017).

Осим што ове лексичке јединице одсликавају Семољ људе и њихов живот, има нешто и у људској природи, у природи приповједача, у народном памћењу, да му се боље у сјећању урежу ријечи које носе јак експресиван набој, а то су често оне са негативним предзнаком, поготово ласцивне, а и приповједачу су чешће „на врху језика”, те су се, као веома упечатљиве, лакше запажале, урезивале у сјећање, памтиле, изговарале у одређеном амбијенту, нарочито над бијелим папиром. Како је Семољ човјек именован семољ ријечју („Име је ријеч!”), без обзира на то да ли ријеч-име носи негативну конотацију или не, у причи о ријечима-људима су наслаге и позитивног и негативног, тешког и бременитог, из којег, као из семоља, израста Семољ човјек, живећи свој семољски живот, преживљавајући семољски семољ. Можда по оном народном: „Што нас не уби, то нас ојача". Тако Семољ људе није убио ни семољ ни ријечи, неко их је исклесао у њиховом семољу, и семољ у њима. Да трају и истрајавају у причи Семољ љуgи о њима самима, Семољ људима.

\section{Литература}

Белић 1931: Александар Белић, Срйски језик (образоваюе речи - сложенице и суфикси), Београд.

Белић 2000: Александар Белић, Савремени срӣскохрвайски књижевни језик. Друіи gео: Наука о ірађену речи, Александар Белић, Изабрана дела 14, Универзитетска предавања из савременог српскохрватског језика. Библиографија радова, Београд: Завод за уџбенике и наставна средства. 
Вуксановић 2011: Миро Вуксановић, Семољ љууди. Азбучни ромсн у 919 иррича о наgимиима, Београд: Београдска књига. Вялкина 1996: Л. В. Вялкина, Словообразовательная структура сложных слов в древнерусском языке XI-XIV вв., Лексиколоїия и словообразование яревнерусскоі̄о языка. Москва: Наука, 156-195.

Грковић-Мејџор 2007: Јасмина Грковић-Мејџор, „Сложенице у роману Варлаам и Јоасаф (Хил. 422)”. Сйиси из исӣоријске линівисиичке. Нови Сад - Сремски Карловци: Издавачка књижарница Зорана Стојановића, 397-412.

Караџић 1852: Вук Стефановић Караџић, Срӣски рјечник. Истиумачен юемачкијем и таииинскијем ријечима, У Бечу у штампарији јерменског намастира.

Клајн 2002: Иван Клајн, Творба речи у савременом срӣском језику. Део 1. Слагање и префиксација. Београд - Нови Сад: Завод за уџбенике и наставна средства - Институт за српски језик САНУ - Матица српска.

Кочев И. - Кочева Е., Домусчиева Л. 1988: Иван Кочев - Емилия Кочева, Лиляна Домусчиева, „О народной основе словообразовательных моделей сложных существительных в староболгарском языке”. Х межgународен конірес на слави-

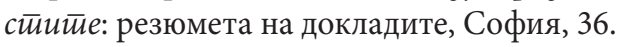

Маројевић 2005: Радмило Маројевић, Творба речи у савременом српском језику Ивана Клајна (1), Срйски језик, број $\mathrm{X} / 1-2$, Београд, 685-781.

Николић 1972-1973: Берислав Николић, Основни принципи творбе у речи у савременом српскохрватском књижевном језику, Наш језик ХІХ, св. 1, стр. 7-20; св. 2-3, стр. 142154; св. 4-5, стр. 273-286.

Радић 2013: Јованка Радић, „Спојни вокал: граматичка реалност или граматичарска конструкција”, Траguција и иновације у савременом срйском језику, Крагујевац: Филолошко-уметнички факултет у Крагујевцу, 25-42.

Симић 2001: Радоје Симић, Срйска ірамайика I, Београд: МX Актуел.

Стевановић 1991: Михаило Стевановић, Савремени срӣскохрвайски језик I, Београд: Нучна књига. 
Станојчић - Поповић 1999: Живојин Станојчић, Љубомир Поповић, Грамайика срӣскої језика за I, II, III и IV разреg среgюе школе, Београд: Завод за уџбенике и наставна средства.

Стојановић 2018: Јелица Стојановић, Сложенице у Вуковом Рјечнику, Међународни научни скуп слависта у Вукове дане: Српска лексикографија - речници српског језика као Изворишта граматичких и семантичких истарживања, 47/1, Београд, 209-219.

Ћупић Д. - Ћупић Ж. 1997: Драго Ћупић - Жељко Ћупић,

Речник говора Загарача, Срӣски gијалекӣолошки зборник XLIV.

Škaljić 1996: Abdulah Škaljić, Turcizmi u srpskohrvatskom jeziku, „Svjetlost” Izdavačko preduzeće, Sarajevo.

Jelica Stojanović

\section{LES GENS DE LA RÉGION MONTAGNARDE SEMOLJ DANS LE MIROIR DES MOTS COMPOSÉS DU ROMAN LES GENS DE SEMOLJ DE L'ÉCRIVAIN MIRO VUKSANOVIC}

Dans cet article, nous avons présenté les mots à deux bases dans le roman Les gens de Semolj de l'écrivain Miro Vuksanovic.

Le corpus constitué a montré que le champ lexical des mots composés de deux bases est répandu dans le roman Les gens de Semolj ainsi que dans la langue serbe.

Nous avons classifié les mots avec deux bases dans les catégories morphologiques correspondantes, parmi lesquelles nous distinguons les différents groupes et modèles morphologiques.

Nous avons porté notre attention particulière à la composition lexicale des mots composés. En analysant ce type de mots, nous avons essayé de présenter à la fois les caractéristiques des gens de Semolj dans ce roman dont chaque histoire qui se suit reprend 
l'ordre alphabétique. Les 919 récits sont construits à partir d'un surnom et ils décrivent les gens de Semolj, leurs caractères et leurs caractéristiques, leurs portraits et leur vie.

D'après notre corpus, les gens de Semolj ont très souvent obtenu une qualification personnelle avec une connotation négative. Les caractéristiques positives sont très rares et rarement mentionnées. Ce n'est pas étonnant, car c'est tout à fait en accord avec la terre aride d’où est issu le mot «semolj » qui s'est répandu à la fois sur cette terre et sur ses gens.

Les mots clés : Mots à deux bases, mots composés, mots composés dérivés, base morphologique, contenu lexical, suffixe, infixe, connotation positive, connotation négative, mots lascifs. 